4

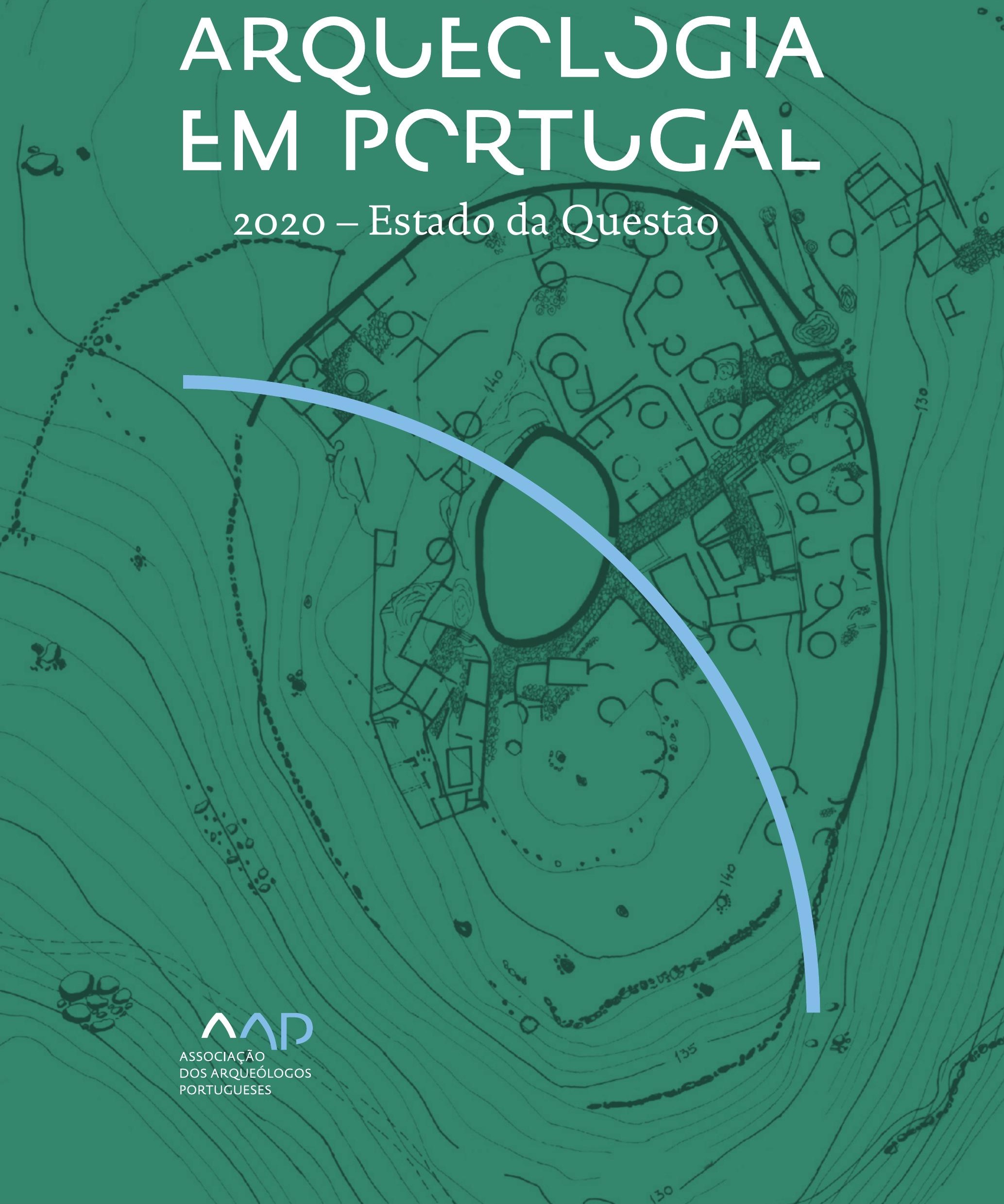


Coordenação editorial: José Morais Arnaud, César Neves e Andrea Martins Design gráfico: Flatland Design

AAP - ISBN: 978-972-9451-89-8

CITCEM - ISBN: 978-989-8970-25-1

Associação dos Arqueólogos Portugueses e CITCEM

Lisboa, 2020

O conteúdo dos artigos é da inteira responsabilidade dos autores. Sendo assim a Associação dos Arqueólogos Portugueses declina qualquer responsabilidade por eventuais equívocos ou questões de ordem ética e legal.

Desenho de capa:

Planta do castro de Monte Mozinho (Museu Municipal de Penafiel).

\section{$\hat{\wedge} \mathrm{P}$}

DOS ARQUEÓLOGOS PORTUGUESES

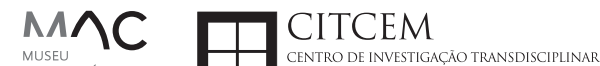
MUSEU
ARQUELLÓGICO
DO CARMO
U.PORTO

FLUP FACULDADE DE LETRAS
UNIVERSIDADE DO PORTO

Apoio

EC para a Ciência 


\section{Índice}

15 Prefácio

José Morais Arnaud

\section{Historiografia e Teoria}

17 Território, comunidade, memória e emoção: a contribuição da história da arqueologia (algumas primeiras e breves reflexões)

Ana Cristina Martins

25 Como descolonizar a arqueologia portuguesa?

Rui Gomes Coelho

41 Arqueologia e Modernidade: uma revisitação pessoal e breve de alguns aspetos da obra homónima de Julian Thomas de 2004

Vítor Oliveira Jorge

57 Dados para a História das Mulheres na Arqueologia portuguesa, dos finais do século XIX aos inícios do século XX: números, nomes e tabelas

Filipa Dimas / Mariana Diniz

73 Retractos da arqueologia portuguesa na imprensa: (in)visibilidades no feminino

Catarina Costeira / Elsa Luís

85 Arqueologia e Arqueólogos no Norte de Portugal Jacinta Bugalhão

101 Vieira Guimarães (1864-1939) e a arqueologia em Tomar: uma abordagem sobre o território e as gentes

João Amendoeira Peixoto / Ana Cristina Martins

115 Os memoráveis? A arqueologia algarvia na imprensa nacional e regional na presente centúria (2001-2019): características, visões do(s) passado(s) e a arqueologia

enquanto marca

Frederico Agosto / João Silva

129 A Evolução da Arqueologia Urbana e a Valorização Patrimonial no Barlavento Algarvio: Os casos de Portimão e Silves

Artur Mateus / Diogo Varandas / Rafael Boavida

\section{Gestão, Valorização e Salvaguarda do Património}

145 O Caderno Reivindicativo e as condições de trabalho em Arqueologia Miguel Rocha / Liliana Matias Carvalho / Regis Barbosa / Mauro Correia / Sara Simões / Jacinta Bugalhão / Sara Brito / Liliana Veríssimo Carvalho / Richard Peace / Pedro Peça / Cézer Santos

155 Os Estudos de Impacte Patrimonial como elemento para uma estratégia sustentável de minimização de impactes no âmbito de reconversões agrícolas Tiago do Pereiro

165 Salvaguarda de Património arqueológico em operações florestais: gestão e sensibilização Filipa Bragança / Gertrudes Zambujo / Sandra Lourenço / Belém Paiva / Carlos Banha / Frederico Tatá Regala / Helena Moura / Jacinta Bugalhão / João Marques / José Correia / Pedro Faria / Samuel Melro

179 Os valores do Património: uma investigação sobre os Sítios Pré-históricos de Arte Rupestre do Vale do Rio Côa e de Siega Verde José Paulo Francisco 
189 Conjugando recursos arqueológicos e naturais para potenciar as visitas ao Geoparque Litoral de Viana do Castelo (Noroeste de Portugal)

Hugo A. Sampaio / Ana M.S. Bettencourt / Susana Marinho / Ricardo Carvalhido

203 Áreas de Potencial Arqueológico na Região do Médio Tejo: Modelo Espacial Preditivo Rita Ferreira Anastácio / Ana Filipa Martins / Luiz Oosterbeek

223 Património Arqueológico e Gestão Territorial: O contributo da Arqueologia para a revisão do PDM de Avis

Ana Cristina Ribeiro

237 A coleção arqueológica do extinto Museu Municipal do Porto - Origens, Percursos e Estudos

Sónia Couto

251 Valpaços - uma nova carta arqueológica

Pedro Pereira / Maria de Fátima Casares Machado

263 Arqueologia na Cidade de Peniche

Adriano Constantino / Luís Rendeiro

273 Arqueologia Urbana: a cidade de Lagos como caso de Estudo Cátia Neto

285 Estratégias de promoção do património cultural subaquático nos Açores. O caso da ilha do Faial

José Luís Neto / José Bettencourt / Luís Borges / Pedro Parreira

297 Carta Arqueológica da Cidade Velha: Uma primeira abordagem

Jaylson Monteiro / Nireide Tavares / Sara da Veiga / Claudino Ramos / Edson Brito /

Carlos Carvalho / Francisco Moreira / Adalberto Tavares

311 Antropologia Virtual: novas metodologias para a análise morfológica e funcional Ricardo Miguel Godinho / Célia Gonçalves

\section{Didáctica da Arqueologia}

327 Como os projetos de Arqueologia podem contribuir para uma comunidade culturalmente mais consciente Alexandra Figueiredo / Claúdio Monteiro / Adolfo Silveira / Ricardo Lopes

337 Educação Patrimonial - Um cidadão esclarecido é um cidadão ativo! Ana Paula Almeida

351 A aproximação da Arqueologia à sala de aula: um caso de estudo no $3^{\circ}$ ciclo do Ensino Básico Luís Serrão Gil

363 Arqueologia 3.o - Pensar e comunicar a Arqueologia para um futuro sustentável Mónica Rolo

377 “Conversa de Arqueólogos" - Divulgar a Arqueologia em tempos de Pandemia Diogo Teixeira Dias

389 Escola Profissional de Arqueologia: desafios e oportunidades Susana Nunes / Dulcineia Pinto / Júlia Silva / Ana Mascarenhas

399 Os Museus de Arqueologia e os Jovens: a oferta educativa para o público adolescente Beatriz Correia Barata / Leonor Medeiros

411 O museu universitário como mediador entre a ciência e a sociedade: o exemplo da secção de arqueologia no Museu de História Natural e da Ciência da Universidade do Porto (MHNC-UP)

Rita Gaspar 
421 Museu de Lanifícios: Real Fábrica de Panos. Atividades no âmbito da Arqueologia Beatriz Correia Barata / Rita Salvado

427 Arqueologia Pública e o caso da localidade da Mata (Torres Novas) Cláudia Manso / Ana Rita Ferreira / Cristiana Ferreira / Vanessa Cardoso Antunes

431 Do sítio arqueológico ao museu: um percurso (também) didático Lídia Fernandes

447 Estão todos convidados para a Festa! E para dançar também... O projecto do Serviço Educativo do Museu Arqueológico do Carmo na $5^{\underline{a}}$ Edição da Festa da Arqueologia Rita Pires dos Santos

459 O “Clã de Carenque”, um projeto didático de arqueologia Eduardo Gonzalez Rocha

469 Mediação cultural: peixe que puxa carroça nas Ruínas Romanas de Troia Inês Vaz Pinto / Ana Patrícia Magalhães / Patrícia Brum / Filipa Santos

481 Didática Arqueológica, experiências do Projeto Mértola Vila Museu Maria de Fátima Palma / Clara Rodrigues / Susana Gómez / Lígia Rafael

\section{Arte Rupestre}

497 Os inventários de arte rupestre em Portugal Mila Simões de Abreu

513 O projeto FIRST-ART - conservação, documentação e gestão das primeiras manifestações de arte rupestre no Sudoeste da Península Ibérica: as grutas do Escoural e Maltravieso Sara Garcês / Hipólito Collado / José Julio García Arranz / Luiz Oosterbeek / António Carlos Silva / Pierluigi Rosina / Hugo Gomes / Anabela Borralheiro Pereira / George Nash / Esmeralda Gomes / Nelson Almeida / Carlos Carpetudo

523 Trabalhos de documentação de arte paleolítica realizados no âmbito do projeto PalæoCôa André Tomás Santos / António Fernando Barbosa / Luís Luís / Marcelo Silvestre / Thierry Aubry

537 Imagens fantasmagóricas, silhuetas elusivas: as figuras humanas na arte do Paleolítico Superior da região do Côa Mário Reis

$55^{1}$ Os motivos zoomórficos representados nas placas de tear de Vila Nova de São Pedro (Azambuja, Portugal) Andrea Martins / César Neves / José M. Arnaud / Mariana Diniz

571 Arte Rupestre do Monte de Góios (Lanhelas, Caminha). Síntese dos resultados dos trabalhos efectuados em 2007-2009 Mário Varela Gomes

599 Gravuras rupestres de barquiformes no Monte de S. Romão, Guimarães, Noroeste de Portugal Daniela Cardoso

613 Círculos segmentados gravados na Bacia do Rio Lima (Noroeste de Portugal): contributos para o seu estudo Diogo Marinho / Ana M.S. Bettencourt / Hugo Aluai Sampaio

631 Equídeos gravados no curso inferior do Rio Mouro, Monção (NW Portugal). Análise preliminar Coutinho, L.M. / Bettencourt, A.M.S / Sampaio, Hugo A.S

645 Paletas na Arte Rupestre do Noroeste de Portugal. Inventário preliminar Bruna Sousa Afonso / Ana M. S. Bettencourt / Hugo A. Sampaio 


\section{Pré-História}

661 O projeto Miño/Minho: balanço de quatro anos de trabalhos arqueológicos Sérgio Monteiro-Rodrigues / João Pedro Cunha-Ribeiro / Eduardo Méndez-Quintas / Carlos Ferreira / Pedro Xavier / José Meireles / Alberto Gomes / Manuel Santonja / Alfredo Pérez-González

677 A ocupação paleolítica da margem esquerda do Baixo Minho: a indústria lítica do sítio de Pedreiras 2 (Monção, Portugal) e a sua integração no contexto regional Carlos Ferreira / João Pedro Cunha-Ribeiro / Sérgio Monteiro-Rodrigues / Eduardo Méndez-Quintas / Pedro Xavier / José Meireles / Alberto Gomes / Manuel Santonja / Alfredo Pérez-González

693 O sítio acheulense do Plistocénico médio da Gruta da Aroeira Joan Daura / Montserrat Sanz / Filipa Rodrigues / Pedro Souto / João Zilhão

703 As sociedades neandertais no Barlavento algarvio: modelos preditivos com recurso aos SIG

Daniela Maio

715 A utilização de quartzo durante o Paleolítico Superior no território dos vales dos rios Vouga e Côa

Cristina Gameiro / Thierry Aubry / Bárbara Costa / Sérgio Gomes / Luís Luís / Carmen Manzano / André Tomás Santos

733 Uma perspetiva diacrónica da ocupação do concheiro do Cabeço da Amoreira (Muge, Portugal) a partir da tecnologia lítica Joana Belmiro / João Cascalheira / Célia Gonçalves

745 Novos dados sobre a Pré-história Antiga no concelho de Palmela. A intervenção arqueológica no sítio do Poceirão I

Michelle Teixeira Santos

757 Problemas em torno de Datas Absolutas Pré-Históricas no Norte do Alentejo Jorge de Oliveira

771 Povoamento pré-histórico nas áreas montanhosas do NO de Portugal: o Abrigo 1 de Vale de Cerdeira Pedro Xavier / José Meireles / Carlos Alves

783 Apreciação do povoamento do Neolítico Inicial na Baixa Bacia do Douro. A Lavra I (Serra da Aboboreira) como caso de estudo Maria de Jesus Sanches

797 O Processo de Neolitização na Plataforma do Mondego: os dados do Sector C do Outeiro dos Castelos de Beijós (Carregal do Sal)

João Carlos de Senna-Martinez / José Manuel Quintã Ventura / Andreia Carvalho / Cíntia Maurício

823 Novos trabalhos na Lapa da Bugalheira (Almonda, Torres Novas) Filipa Rodrigues / Pedro Souto / Artur Ferreira / Alexandre Varanda / Luís Gomes / Helena Gomes / João Zilhão

837 A pedra polida e afeiçoada do sítio do Neolítico médio da Moita do Ourives (Benavente, Portugal)

César Neves

857 Casal do Outeiro (Encarnação, Mafra): novos contributos para o conhecimento do povoamento do Neolítico final na Península de Lisboa.

Cátia Delicado / Carlos Maneira e Costa / Marta Miranda / Ana Catarina Sousa

873 Stresse infantil, morbilidade e mortalidade no sítio arqueológico do Neolítico Final/ Calcolítico ( $4^{\circ}$ e $3^{\circ}$ milénio a.C.) do Monte do Carrascal 2 (Ferreira do Alentejo, Beja) Liliana Matias de Carvalho / Sofia N. Wasterlain 
885 Come together: O Conjunto Megalítico das Motas (Monção, Viana do Castelo) e as expressões Campaniformes do Alto Minho Ana Catarina Basílio / Rui Ramos

899 Trabalhos arqueológicos no sítio Calcolítico da Pedreira do Poio Carla Magalhães / João Muralha / Mário Reis / António Batarda Fernandes

913 O sítio arqueológico de Castanheiro do Vento. Da arquitectura do sítio à arquitectura de um território João Muralha Cardoso

925 Estudo zooarqueológico das faunas do Calcolítico final de Vila Nova de São Pedro (Azambuja, Portugal): Campanhas de 2017 e 2018 Cleia Detry / Ana Catarina Francisco / Mariana Diniz / Andrea Martins / César Neves / José Morais Arnaud

943 As faunas depositadas no Museu Arqueológico do Carmo provenientes de Vila Nova de São Pedro (Azambuja): as campanhas de 1937 a 1967 Ana Catarina Francisco / Cleia Detry / César Neves / Andrea Martins / Mariana Diniz / José Morais Arnaud

959 Análise funcional de material lítico em sílex do castro de Vila Nova de S. Pedro (Azambuja, Portugal): uma primeira abordagem Rafael Lima

971 O recinto da Folha do Ouro 1 (Serpa) no contexto dos recintos de fossos calcolíticos alentejanos

António Carlos Valera / Tiago do Pereiro / Pedro Valério / António M. Monge Soares

\section{Proto-História}

987 Produção de sal marinho na Idade do Bronze do noroeste Português. Alguns dados para uma reflexão

Ana M. S. Bettencourt / Sara Luz / Nuno Oliveira / Pedro P. Simões / Maria Isabel C. Alves / Emílio Abad-Vidal

1001 A estátua-menir do Pedrão ou de São Bartolomeu do Mar (Esposende, noroeste de Portugal) no contexto arqueológico da fachada costeira de entre os rios Neiva e Cávado Ana M. S. Bettencourt / Manuel Santos-Estévez / Pedro Pimenta Simões / Luís Gonçalves

1015 O Castro do Muro (Vandoma/Baltar, Paredes) - notas para uma biografia de ocupação da Idade do Bronze à Idade Média

Maria Antónia D. Silva / Ana M. S. Bettencourt / António Manuel S. P. Silva / Natália Félix

1031 Do Bronze Final à Idade Média - continuidades e hiatos na ocupação de Povoados em Oliveira de Azeméis João Tiago Tavares / Adriaan de Man

1041 As faunas do final da Idade do Bronze no Sul de Portugal: leituras desde o Outeiro do Circo (Beja)

Nelson J. Almeida / Íris Dias / Cleia Detry / Eduardo Porfírio / Miguel Serra

1055 A Espada do Monte das Oliveiras (Serpa) - uma arma do Bronze Pleno do Sudoeste Rui M. G. Monge Soares / Pedro Valério / Mariana Nabais / António M. Monge Soares

1065 São Julião da Branca (Albergaria-a-Velha) - Investigação e valorização de um povoado do Bronze Final

António Manuel S. P. Silva / Paulo A. P. Lemos / Sara Almeida e Silva / Edite Martins de Sá

1083 Do castro de S. João ao Mosteiro de Santa Clara: notícia de uma intervenção arqueológica, em Vila do Conde Rui Pinheiro 
1095 O castro de Ovil (Espinho), um quarto de século de investigação - resultados e questões em aberto

Jorge Fernando Salvador / António Manuel S. P. Silva

1111 O Castro de Salreu (Estarreja), um povoado proto-histórico no litoral do Entre Douro e Vouga

Sara Almeida e Silva / António Manuel S. P. Silva / Paulo A. P. Lemos / Edite Martins de Sá

1127 Castro de Nossa Senhora das Necessidades (Sernancelhe): uma primeira análise artefactual Telma Susana O. Ribeiro

${ }_{1141}$ A cividade de Bagunte. O estado atual da investigação Pedro Brochado de Almeida

1153 Zoomorfos na cerâmica da Idade do Ferro no NW Peninsular: inventário, cronologias e significado Nuno Oliveira / Cristina Seoane

1163 Vasos gregos em Portugal: diferentes maneiras de contar a história do intercâmbio cultural na Idade do Ferro

Daniela Ferreira

1175 Os exotica da necrópole da Idade do Ferro do Olival do Senhor dos Mártires (Alcácer do Sal) no seu contexto regional

Francisco B. Gomes

\section{Antiguidade Clássica e Tardia}

1191 O uso de madeira como combustível no sítio da Quinta de Crestelos (Baixo Sabor): da Idade do Ferro à Romanização Filipe Vaz / João Tereso / Sérgio Simões Pereira / José Sastre / Javier Larrazabal Galarza / Susana Cosme / José António Pereira / Israel Espi

1207 Cultivos de Época Romana no Baixo Sabor: continuidade em tempos de mudança? João Pedro Tereso / Sérgio Simões Pereira / Filipe Santos / Luís Seabra / Filipe Vaz

1221 A casa romana na Hispânia: aplicação dos modelos itálicos nas províncias ibéricas Fernanda Magalhães / Diego Machado / Manuela Martins

1235 As pinturas murais romanas da Rua General Sousa Machado, n. ${ }^{5}$ 1, Chaves José Carvalho

1243 Trás do Castelo (Vale de Mir, Pegarinhos, Alijó) - Uma exploração agrícola romana do Douro

Tony Silvino / Pedro Pereira

1255 A sequência de ocupação no quadrante sudeste de Bracara Augusta: as transformações de uma unidade doméstica Lara Fernandes / Manuela Martins

1263 Os Mosaicos com decoração geométrica e geométrico-vegetalista dos sítios arqueológicos da área do Conuentus Bracaraugustanus. Novas abordagens quanto à conservação, restauro, decoração e datação Maria de Fátima Abraços / Licínia Wrench

1277 “Casa Romana” do Castro de São Domingos (Cristelos, Lousada): Escavação, Estudo e Musealização Paulo André de P. Lemos

1291 A arqueobotânica no Castro de Guifões (Matosinhos, Noroeste de Portugal): O primeiro estudo carpológico

Luís Seabra / Andreia Arezes / Catarina Magalhães / José Varela / João Pedro Tereso 
1305 Um Horreum Augustano na Foz do Douro (Monte do Castelo de Gaia, Vila Nova de Gaia) Rui Ramos

1311 Ponderais romanos na Lusitânia: padrões, formas, materiais e contextos de utilização Diego Barrios Rodríguez

1323 Um almofariz centro-itálico na foz do Mondego

Marco Penajoia

1335 Estruturas romanas de Carnide - Lisboa Luísa Batalha / Mário Monteiro / Guilherme Cardoso

1347 O contexto funerário do sector da "necrópole NO" da Rua das Portas de S. Antão (Lisboa): o espaço, os artefactos, os indivíduos e a sua interconectividade na interpretação do passado Sílvia Loja, José Carlos Quaresma, Nelson Cabaço, Marina Lourenço, Sílvia Casimiro, Rodrigo Banha da Silva, Francisca Alves-Cardoso

${ }_{1361}$ Povoamento em época Romana na Amadora - resultados de um projeto pluridisciplinar Gisela Encarnação / Vanessa Dias

1371 A Arquitectura Residencial em Mirobriga (Santiago do Cacém): contributo a partir de um estudo de caso Filipe Sousa / Catarina Felício

${ }_{1385}$ O fim do ciclo. Saneamento e gestão de resíduos nos edifícios termais de Mirobriga (Santiago do Cacém)

Catarina Felício / Filipe Sousa

1399 Balsa, Topografia e Urbanismo de uma Cidade Portuária Vítor Silva Dias / João Pedro Bernardes / Celso Candeias / Cristina Tété Garcia

1413 No Largo das Mouras Velhas em Faro (2017): novas evidências da necrópole norte de Ossonoba e da sua ocupação medieval Ricardo Costeira da Silva / Paulo Botelho / Fernando Santos / Liliana Nunes

1429 Instrumentos de pesca recuperados numa fábrica de salga em Ossonoba (Faro) Inês Rasteiro / Ricardo Costeira da Silva / Paulo Botelho

1439 A Necrópole Romana do Eirô, Duas Igrejas (Penafiel): intervenção arqueológica de 2016 Laura Sousa / Teresa Soeiro

1457 Ritual, descarte ou afetividade? A presença de Canis lupus familiaris na Necrópole Noroeste de Olisipo (Lisboa)

Beatriz Calapez Santos / Sofia Simões Pereira / Rodrigo Banha da Silva / Sílvia Casimiro / Cleia Detry / Francisca Alves Cardoso

1467 Dinâmicas económicas em Bracara na Antiguidade Tardia Diego Machado / Manuela Martins / Fernanda Magalhães / Natália Botica

1479 Cerâmicas e Vidros da Antiguidade Tardia do Edifício sob a Igreja do Bom Jesus (Vila Nova de Gaia) Joaquim Filipe Ramos

1493 Novos contributos para a topografia histórica de Mértola no período romano e na Antiguidade Tardia Virgílio Lopes

\section{8. Época Medieval}

1511 Cerâmicas islâmicas no Garb setentrional "português": algumas evidências e incógnitas Constança dos Santos / Helena Catarino / Susana Gómez / Maria José Gonçalves / Isabel Inácio / Gonçalo Lopes / Jacinta Bugalhão / Sandra Cavaco / Jaquelina Covaneiro / Isabel Cristina Fernandes / Ana Sofia Gomes 
1525 Contributo para o conhecimento da cosmética islâmica, em Silves, durante a Idade Média Rosa Varela Gomes

1537 Yábura e o seu território - uma análise histórico-arqueológica de Évora entre os séculos VIII-XII José Rui Santos

1547 A encosta sul do Castelo de Palmela - resultados preliminares da escavação arqueológica Luís Filipe Pereira / Michelle Teixeira Santos

1559 A igreja de São Lourenço (Mouraria, Lisboa): um conjunto de silos e de cerâmica medieval islâmica

Andreia Filipa Moreira Rodrigues

1571 O registo material de movimentações populacionais no Médio Tejo, durante os séculos XII-XIII. Dois casos de "sunken featured buildings", nos concelhos de Cartaxo e Torres Novas Marco Liberato / Helena Santos / Nuno Santos

1585 O nordeste transmontano nos alvores da Idade média. Notas para reflexão Ana Maria da Costa Oliveira

1601 Sepulturas escavadas na rocha do Norte de Portugal e do Vale do Douro: primeiros resultados do Projecto SER-NPVD

Mário Jorge Barroca / César Guedes / Andreia Arezes / Ana Maria Oliveira

1619 "Portucalem Castrum Novum" entre o Mediterrâneo e o Atlântico: o estudo dos materiais cerâmicos alto-medievais do arqueossítio da rua de D. Hugo, nํ. 5 (Porto) João Luís Veloso

1627 A Alta Idade Média na fronteira de Lafões: notas preliminares sobre a Arqueologia no Concelho de Vouzela

Manuel Luís Real / Catarina Tente

1641 Um conjunto cerâmico medieval fora de portas: um breve testemunho aveirense Susana Temudo

${ }_{1651}$ Os Lóios do Porto: uma perspetiva integrada no panorama funerário da Baixa Idade Média à Época Moderna em meios urbanos em Portugal

Ana Lema Seabra

1659 O Caminho Português Interior de Santiago como eixo viário na Idade Média Pedro Azevedo

1665 Morfologia Urbana: Um exercício em torno do Castelo de Ourém André Donas-Botto / Jaqueline Pereira

1677 Intervenção arqueológica na Rua Marquês de Pombal/Largo do Espírito Santo (Bucelas, Loures)

Florbela Estêvão / Nathalie Antunes-Ferreira / Dário Ramos Neves / Inês Lisboa

1691 O Cemitério Medieval do Poço do Borratém e a espacialidade funerária na cidade de Lisboa Inês Belém / Vanessa Filipe / Vasco Noronha Vieira / Sónia Ferro / Rodrigo Banha da Silva

1705 Um Espaço Funerário Conventual do séc. XV em Lisboa: o caso do Convento de São Domingos da Cidade Sérgio Pedroso / Sílvia Casimiro / Rodrigo Banha da Silva / Francisca Alves Cardoso

\section{9. Época Moderna e Contemporânea}

1721 Arqueologia Moderna em Portugal: algumas reflexões críticas em torno da quantificação de conjuntos cerâmicos e suas inferências históricas e antropológicas Rodrigo Banha da Silva / André Bargão / Sara da Cruz Ferreira

1733 Faianças de dois contextos entre os finais do século XVI e XVIII do Palácio dos Condes de Penafiel, Lisboa

Martim Lopes / Tomás Mesquita 
1747 Um perfil de consumo do século XVIII na foz do Tejo: O caso do Mercado da Ribeira, Lisboa Sara da Cruz Ferreira / Rodrigo Banha da Silva / André Bargão

1761 Os Cachimbos dos Séculos XVII e XVIII do Palácio Mesquitela e Convento dos Inglesinhos (Lisboa)

Inês Simão / Marina Pinto / João Pimenta / Sara da Cruz Ferreira / André Bargão / Rodrigo Banha da Silva

1775 "Tomar os fumos da erua que chamão em Portugal erua sancta». Estudo de Cachimbos provenientes da Rua do Terreiro do Trigo, Lisboa

Miguel Martins de Sousa / José Pedro Henriques / Vanessa Galiza Filipe

1787 Cachimbos de Barro Caulínitico da Sé da Cidade Velha (República de Cabo Verde)

Rodrigo Banha da Silva / João Pimenta / Clementino Amaro

1801 Algumas considerações sobre espólio não cerâmico recuperado no Largo de Jesus (Lisboa) Carlos Boavida

1815 Adereços de vidro, dos séculos XVI-XVIII, procedentes do antigo Convento de Santana de Lisboa (anéis, braceletes e contas)

Joana Gonçalves / Rosa Varela Gomes / Mário Varela Gomes

1837 Da ostentação, luxo e poder à simplicidade do uso quotidiano: arqueologia e simbologia de joias e adornos da Idade Moderna Portuguesa Jéssica Iglésias

1849 Os amuletos em Portugal - dos objetos às superstições: o coral vermelho Alexandra Vieira

1865 Cerâmicas de Vila Franca de Xira nos séculos XV e XVI Eva Pires

1879 «Não passa por teu o que me pertence». Marcas de individualização associadas a faianças do Convento de Nossa Senhora de Aracoeli, Alcácer do Sal Catarina Parreira / Íris Fragoso / Miguel Martins de Sousa

1891 Cerâmica de Leiria: alguns focos de produção

Jaqueline Pereira / André Donas-Botto

1901 Os Fornos na Rua da Biquinha, em Óbidos Hugo Silva / Filipe Oliveira

1909 A casa de Pêro Fernandes, contador dos contos de D. Manuel I: o sítio arqueológico da Silha do Alferes, Seixal (século XVI) Mariana Nunes Ferreira

1921 O Alto da Vigia (Sintra) e a vigilância e defesa da costa Alexandre Gonçalves / Sandra Santos

1937 O contexto da torre sineira da Igreja de Santa Maria de Loures Paulo Calaveira / Martim Lopes

1949 A Necrópole do Hospital Militar do Castelo de São Jorge e as práticas funerárias na Lisboa de Época Moderna Susana Henriques / Liliana Matias de Carvalho / Ana Amarante / Sofia N. Wasterlain

1963 SAND - Sarilhos Grandes Entre dois Mundos: o adro da Igreja e a Paleobiologia dos ossos humanos recuperados

Paula Alves Pereira / Roger Lee Jesus / Bruno M. Magalhães

1975 Expansão urbana da vila de Cascais no século XVII e XVIII: a intervenção arqueológica na Rua da Vitória no 15 a 17

Tiago Pereira / Vanessa Filipe

1987 Novos dados para o conhecimento do Urbanismo de Faro em época Moderna Ana Rosa 
1995 Um exemplo de Arqueologia Urbana em Alcoutim: o Antigo Edifício dos CTT Marco Fernandes / Marta Dias / Alexandra Gradim / Virgílio Lopes / Susana Gómez Martínez

2007 Palácio dos Ferrazes (Rua das Flores/Rua da Vitória, Porto): a cocheira de Domingos Oliveira Maia

Francisco Raimundo

2021 As muitas vidas de um edifício urbano: História, Arqueologia e Antropologia no antigo Recreatório Paroquial de Penafiel Helena Bernardo / Jorge Sampaio / Marta Borges

2035 O convento de Nossa Senhora da Esperança de Ponta Delgada: o contributo da arqueologia para o conhecimento de um monumento identitário João Gonçalves Araújo / N’Zinga Oliveira

2047 Arqueologia na ilha do Corvo... em busca da capela de Nossa Senhora do Rosário Tânia Manuel Casimiro / José Luís Neto / Luís Borges / Pedro Parreira

2059 Perdidos à vista da Costa. Trabalhos arqueológicos subaquáticos na Barra do Tejo Jorge Freire / José Bettencourt / Augusto Salgado

2071 Arqueologia marítima em Cabo Verde: enquadramento e primeiros resultados do projecto CONCHA

José Bettencourt / Adilson Dias / Carlos Lima / Christelle Chouzenoux / Cristóvão Fonseca / Dúnia Pereira / Gonçalo Lopes / Inês Coelho / Jaylson Monteiro / José Lima / Maria Eugénia Alves / Patrícia Carvalho / Tiago Silva

2085 Trabalhos arqueológicos na Cidade Velha (Ribeira Grande de Santiago, Cabo Verde): reflexões sobre um projecto de investigação e divulgação patrimonial André Teixeira / Jaylson Monteiro / Mariana Mateus / Nireide Tavares / Cristovão Fonseca / Gonçalo C. Lopes / Joana Bento Torres / Dúnia Pereira / André Bargão / Aurélie Mayer / Bruno Zélie / Carlos Lima / Christelle Chouzenoux / Inês Henriques / Inês Pinto Coelho / José Lima / Patrícia Carvalho / Tiago Silva

2103 A antiga fortificação de Quelba / Khor Kalba (E.A.U.). Resultados de quatro campanhas de escavações, problemáticas e perspectivas futuras Rui Carita / Rosa Varela Gomes / Mário Varela Gomes / Kamyar Kamyad

2123 Colónias para homens novos: arqueologia da colonização agrária fascista no noroeste ibérico Xurxo Ayán Vila / José Mạ . Señorán Martín 


\title{
A SEQUÊNCIA DE OCUPAÇÃO NO QUADRANTE SUDESTE DE BRACARA AUGUSTA: AS TRANSFORMAÇÕES DE UMA UNIDADE DOMÉSTICA
}

\author{
Lara Fernandes ${ }^{1}$, Manuela Martins ${ }^{2}$
}

\begin{abstract}
RESUMO
Os trabalhos de escavação realizados nos terrenos da Santa Casa de Misericórdia de Braga, entre 1999 e 200o, permitiram colocar a descoberto um conjunto de estruturas que se viriam a revelar importantes para o estudo do urbanismo e da arquitetura doméstica da época romana, uma vez que se situam num setor da cidade com grande potencial arqueológico e reduzida sobreposição construtiva, em terrenos abandonados posteriormente à Antiguidade Tardia. Neste artigo pretende-se dar a conhecer algumas das estruturas escavadas que formalizam uma unidade doméstica inserida num quarteirão da cidade romana de Bracara Augusta, construída no Alto Império e remodelada no período tetrárquico. Para tal, serão valorizados os vestígios identificados na intervenção no Tabuleiro A dos Terrenos da Santa Casa de Misericórdia de Braga.
\end{abstract}

Palavras-chave: Bracara Augusta, Urbanismo romano, Domus.

\begin{abstract}
The excavation work carried out on the ground of the Santa Casa da Misericórdia in Braga between 1999 and 200o, helped to uncover a set of structures that would prove to be important for the study of the urbanism and the domestic architecture of the Roman era, as it is located in a sector of the city with a great archeological potential and little constructive overlap, in territories abandoned after the Late Antiquity, In this article we inted to make know some of the excaveted stuctures that formalize a domestic unit inserted in a block of the Roman city of Bracara Augusta, built in the High Empire and remodeled in the tetrarchic period. To this end, the traces identified in the intervention in Tabuleiro A of the ground of the Santa Casa da Misericórdia in Braga will be assessed.
\end{abstract}

Keywords: Bracara Augusta, Roman urbanism, Domus.

\section{INTRODUÇÃO}

O estudo de Bracara Augusta é devedor do projeto iniciado em 1977 pela Unidade de Arqueologia da Universidade do Minho, no âmbito do qual se têm vindo a realizar trabalhos arqueológicos sistemáticos na cidade de Braga ao longo das últimas quatro décadas. Apesar dos constrangimentos naturalmente associados à arqueologia urbana, designadamente os que decorrem do facto do avanço das escavações serem determinadas, em grande medi- da, pela atividade construtiva, a cidade romana, que deu origem à Braga moderna, vem sendo objeto de consideráveis avanços no conhecimento relativo ao urbanismo, arquitetura e economia.

Com efeito, a partir de uma análise do conjunto de vestígios de ruas, pórticos e edificados foi possível restituir, com bastante segurança, o traçado da malha urbana fundacional da cidade, globalmente composta por eixos viários que replicam paralelamente o cardo e o decumano máximos, as artérias principais da cidade, que formalizou uma morfo-

1. Bolseira de Investigação da Unidade de Arqueologia da Universidade do Minho; lararitafernandes@gmail.com

2. Professora Catedrática da UMinho e investigadora do Lab2PT; mmmartins@uaum.uminho.pt 
logia urbana ortogonal, na origem de quarteirões regulares e homogéneos, de forma quadrada e a dimensão de 1 actus de lado (Martins $\&$ alii, 2017).

Se o estudo da malha urbana tem a capacidade de conjugar dados provenientes de intervenções realizadas em lotes dispersos, pontuais e, por vezes, distantes, mais difícil se afigura, contudo, a valorização de aspetos arquitetónicos dos edifícios que compunham os equipamentos públicos e o parque habitacional bracaraugustano. Com efeito, o resultado das intervenções arqueológicas, que muitas vezes se resumem a pequenas sondagens dispersas, um pouco por toda a cidade, é um conhecimento ainda parcelar de estruturas que permitem sugerir a restituição parcial das planimetrias dos edifícios (Magalhães, 2010). Contudo, e através do estudo sistemático dos vestígios que vão sendo exumados na cidade, alguns dos edifícios públicos são já conhecidos, de que é exemplo o teatro, cuja planta apresenta uma caraterística simetria que permitiu a sua restituição (Martins \& alii, 2013). Também o exaustivo estudo de amplas áreas escavadas, como acontece com a domus das Carvalheiras, ou de estruturas de várias intervenções, ou dispostas em áreas contíguas, de que é exemplo a domus da Escola Velha da Sé/rua Frei Caetano Brandão, têm permitido restituir a planta de alguns quarteirões romanos e respetivas unidades domésticas (Magalhães, 2019).

Porém, se os estudos sobre a cidade e os seus edifícios conheceram avanços, ora lentos ora significativos, ao sabor da atividade construtiva de Braga, há um setor de Bracara Augusta que é deveras deficitário de trabalhos arqueológicos. Com efeito, uma vez que a Santa Casa da Misericórdia de Braga é detentora de vastos terrenos que compunham o quadrante sudeste da cidade romana, os conhecimentos sobre esta área são consideravelmente menores do que os que possuímos sobre os demais setores de Bracara Augusta. Neste sentido, propomos com este trabalho valorizar os dados provenientes de uma das poucas intervenções realizadas nos terrenos da Santa Casa de Misericórdia, com o intuito de melhor divulgar a arquitetura doméstica da cidade romana.

\section{ENQUADRAMENTO DA ZONA ARQUEOLÓGICA}

A zona arqueológica da Santa Casa de Misericórdia localiza-se na União de Freguesias de S. José de São Lázaro e S. João do Souto, em Braga, e foi dividida em duas plataformas, designadas por tabuleiros superior (A) e inferior (B). No primeiro, situado a oeste do antigo Hospital Distrital de São Marcos (Figura 1), foram realizados trabalhos arqueológicos pela Unidade de Arqueologia da Universidade do Minho (UAUM), entre maio de 1999 e março de 2000 , tendo em vista a instalação de um pavilhão com fins educativos.

A intervenção neste local exigiu a realização de seis sondagens de $4 \times 4 \mathrm{~m}$, abertas em momentos diferentes. Inicialmente, procedeu-se à abertura de três sondagens ( $\mathrm{S}_{25}, \mathrm{P}_{25}$ e M26), as quais revelaram algumas estruturas de interesse arqueológico, optando-se de seguida pela abertura de mais três (Q26, $\mathrm{O}_{25}$ e N25) com o propósito de compreender a continuidade dos dados exumados.

A importância e o potencial arqueológico destes terrenos já tinham sido confirmados no ano de 1977/78 pelas sondagens geofísicas de Garchy, trabalhos de prospeção por resistividade elétrica (Alves, 2016), que se realizaram em diferentes pontos da cidade de Braga, confirmando onde era previsível a existência de ruínas (Delgado, Martins \& Lemos, 1989). Tendo sido o Tabuleiro A dos Terrenos da Misericórdia abarcados pela prospeção levada a cabo foi possível verificar a existência de estruturas que se viriam a revelar importantes para compreender o urbanismo romano de Braga.

Trata-se de um terreno que se integra no quadrante sudeste da cidade romana, organizada em quarteirões, tendo a escavação aí realizada permitido identificar vestígios de uma habitação romana, possibilitando localizar o limite sul de um dos quarteirões e validar a localização de um dos pórticos que ladeava a casa e, consequentemente, confirmar a orientação da ruas que delimitavam o quarteirão, apoiando mais uma vez a malha rigorosamente ortogonal da cidade romana, defendida desde inícios da década de 90 do século XX (Martins, 1995; 2004; 2009; 2014; Martins \& Delgado, 1989-9o) (Figura 2).

\section{A PRIMEIRA FASE DE OCUPAÇÃO}

A análise destes contextos possibilitou identificar um conjunto de vestígios compostos por muros e fundações, de tipologia e cronologia romanas, o que nos permitiu estabelecer uma longa ocupação deste local, balizada entre o século I e a época moderna, no que consideramos ser passível de dividir em três fases. Os vestígios identificados aquando da escavação desta zona arqueológica encontram-se no inte- 
rior de um quarteirão delimitado pelos decumanos D8 e D9 e pelos cardos $\mathrm{K}_{4}$ e $\mathrm{K}_{5}$, tendo em conta a numeração que foi recentemente proposta (Martins $\&$ alii, 2017) (Figura 3 ).

Como nota prévia, é de destacar que não foram identificados os característicos silhares do período augustano, delimitadoras dos quarteirões, o que pode ser justificado tendo em conta que a área escavada não abarcou as esquinas da insula. Desta forma, podemos considerar a primeira fase de ocupação no Tabuleiro $\mathrm{A}$, datável do século $\mathrm{I}$, à qual correspondem grandes valas abertas no substrato rochoso para a implantação de muros, pertencentes a uma construção de cariz habitacional. Admite-se que estaremos perante uma domus de peristilo, que se desenvolvia na área a norte do pórtico que ladeava o decumano 9. Os pórticos na cidade de Bracara Augusta são característicos da construção doméstica do Alto Império (Martins $\&$ alii, 2017), sendo possível identificar a sua presença em todas as estruturas de cariz habitacional escavadas até hoje, de que são exemplos as Zonas Arqueológicas das Carvalheiras, Escola Velha da Sé/rua Frei Caetano Brandão nºs166-168, Frei Caetano Brandão nos 183-185/Santo António das Travessas nos 20-26, Ex Albergue Distrital, rua Afonso Henriques nºs 42-56 e Antigas Cavalariças (Magalhães, 2019).

A casa identificada nos terrenos do Tabuleiro A apresenta vestígios que confirmam esta característica do urbanismo bracaraugustano, sendo possível verificar o desenvolvimento de um pórtico a sul da habitação, que se encontrava no alinhamento do cardo 4 e encerrava esse eixo viário a norte. A partir do eixo pedonal abria-se a entrada para a habitação, formalizada por uma porta que era ladeada por dois silhares, individualizados com as UEso73 e 085 , que deveriam suportar duas colunas, que certamente funcionariam como um elemento decorativo de prestígio, assinalando talvez o estatuto do proprietário. Associado a um dos silhares UE073, surge um troço de um muro (UEo84), a uma distância de aproximadamente $3,6 \mathrm{~m}$ do limite sul do quarteirão. Trata-se de elementos cuja projeção sobre a malha urbana proposta para Bracara Augusta sugerem que definiam a área do pórtico que se desenvolveria na fachada sul da habitação, cuja profundidade colhe paralelos com os demais quarteirões da cidade nos quais os eixos pedonais apresentam sensivelmente a largura de 12 pés (Martins $\&$ alii, 2017).

Uma vez analisadas as áreas externas da domus, pas- samos agora a analisar as estruturas alusivas ao interior da habitação. Constituem-se como elementos construídos associados ao primeiro compartimento acedido através da entrada sul uma área interna delimitada por três muros UEo82 (a sul), UE104 (a oeste) e UEo18 (a norte) e que apresenta silhares (UE043, 102 e 111), facto que indica corresponder a uma área porticada, pelo que julgamos poder ser atribuída ao peristilo da habitação. Com efeito, logo a norte dos silhares que materializam a porta da casa (UE073 e UE085), encontramos um muro de orientação E/O (UEo82), o qual apresenta no seu alinhamento um silhar (UE1O2) que parece formar o limite sul da área aberta. Por sua vez, adossado ao referido silhar, encontra-se um outro muro, com orientação N/S (UE104), registado numa extensão de aproximadamente $12 \mathrm{~m}$, certamente o limite oeste do peristilo, perpendicular a um outro muro com orientação E/O (UEo18), que delimitava aquele espaço aberto a norte.

Além dos elementos de delimitação referidos foi possível identificar ainda alguns dos silhares que sustentavam a colunata do jardim, de que são exemplo aquele individualizado com a UE104, localizado a $8 \mathrm{~m}$ do início do muro UE104, bem como o bloco UE111, que corresponderia ao limite nordeste. Não obstante, é possível observar a presença de alguns negativos referentes ao saque destes elementos arquitetónicos (UEo28 e UEo29), atividade certamente associada à procura por blocos graníticos de qualidade. O cálculo da distância entre estes elementos indica que neste local existiria um intercolúnio de $2 \mathrm{~m}$ para o limite oeste desta área, o que nos leva a crer que o mesmo ocorreria no lado este, tendo em consideração a simetria que se verifica nestes espaços. Por outro lado, no limite sul, é possível estimar um intercolúnio de $3 \mathrm{~m}$, que nos é indicado pelos embasamentos dos dois silhares a nascente (UEo73 e 085). Desta forma podemos então considerar que a área porticada do interior da domus em análise, apresenta uma planta retangular, com $108 \mathrm{~m}^{2}$ ( $\left.9 \times 12 \mathrm{~m}\right)$, que possuiria um total de 18 colunas, sendo que o limite sul e norte possuiriam quatro colunas cada, separadas entre si $3 \mathrm{~m}$ e os limites este e oeste cinco colunas cada, separadas $2 \mathrm{~m}$ entre si (Figura 4).

Podemos ainda calcular a área de ambulacrum que envolveria o jardim colunado, tendo em conta a distância entre o limite sul do peristilo (UEo82) e a fachada sul da habitação (UEo84), que apresenta uma largura de $2,5 \mathrm{~m}$. Considerando agora todos 
os dados apresentados acreditamos poder concluir que existiria uma área ajardinada, rodeada por um ambulacrum com $14 \mathrm{~m}$ de largura e $17 \mathrm{~m}$ de comprimento perfazendo uma área total de $238 \mathrm{~m}^{2}$, à volta da qual se distribuiriam vários compartimentos, os quais não foram possíveis de identificar aquando da escavação deste local (Figura 5).

A utilização de peristilos para distribuir os compartimentos das habitações é um recurso recorrente em Bracara Augusta, identificado na generalidade das domus. Com efeito, a implantação de jardins porticados parece ter por objetivo a emulação da paisagem urbana bracarense, largamente caraterizada pelo ritmo das colunas dos pórticos que se desenvolviam ao longo dos eixos viários e que permitiam intuir um aspeto de continuidade do espaço externo com o interior das habitações, reforçando o caráter de importância pública que os proprietários das casas pretendiam associar à sua importância política, económica e social (Magalhães, 2019). Apesar da domus do Tabuleiro A das Misericórdia não apresentar um corredor de entrada ou um vestíbulo a separarem a porta do jardim, é notável a implantação das colunas que ladeiam a porta e dialogam tanto com os elementos do porticado externo como interno.

\section{A SEGUNDA FASE DE OCUPAÇÃO}

Na segunda fase de ocupação, balizada entre os finais do século III e os inícios do IV, registamos uma reforma na habitação que alterou significativamente a área interna de peristilo, caracterizada pela implantação de novos muros, que, juntamente com os pré-existentes, passaram a compartimentar a área ajardinada.

O muro que define o limite oeste do peristilo (UE104) articula-se agora com um novo muro perpendicular (UE112) que fecha a área oeste do ambulacrum do peristilo, conformando novos compartimentos, cuja morfologia foi impossível restituir. $\mathrm{Na}$ área interior do peristilo foi registado o reaproveitamento de um muro (UEo18) que limitava o jardim a norte, que apresenta na parte superior um novo aparelho (UEoo2). Este muro, em conjunto com a implantação de outros dois (UEs11o e 108), forma agora um novo compartimento, que se desenvolve a norte do peristilo. Este novo espaço está limitado a sul pelo muro correspondente à UE1o8 e a norte por um novo muro (UE055) que reaproveita uma estrutura já existente (UEo82). A norte, e ocupando parte do que foi ambulacrum que envolvia o peristilo, na fase alto imperial, encontra-se agora um novo muro (UE136) que delimita a poente um outro compartimento, cujo pavimento era revestido em opus signinum (UE135) (Figura 6).

Assim, durante a segunda fase de ocupação deste local observa-se a subdivisão da área interna de peristilo em dois espaços. O mais meridional apresenta uma área aproximada de $42 \mathrm{~m}^{2}(7 \times 6 \mathrm{~m})$ delimitado por três muros conhecidos (UEo82, a sul, UE055, a oeste e UE108, a norte), representando este último, o limite sul de um outro espaço (UEı1o, a oeste e UEııg, a norte), com uma área de aproximadamente $28 \mathrm{~m}^{2}$ (4x7m). A área do antigo ambulacrum é, por sua vez, fechada a oeste e norte por dois novos compartimentos. A norte, dispõe-se um muro (UE136), que limita a oeste uma área pavimentada com opus signinum (UE135), verificando-se a oeste o fecho da construção representado na UE112. Uma vez implantados os dois muros (UEo55 e UE11o), que fecham a área ajardinada, podemos sugerir que se tenha criado um novo corredor de circulação no interior da habitação, correspondente ao espaço formalizado entre estes muros e o outro já existente (UE104).

Embora não seja possível realizar grandes ilações acerca das alterações que a casa sofreu nesse período, uma vez que os limites da intervenção impossibilitam a restituição da planimetria completa do edifício, certamente as reformas realizadas na época tetrárquica alteraram significativamente o seu interior. Com efeito, o sacrifício do peristilo para a implantação de dois espaços leva-nos a supor que outro espaço ajardinado possa ter sido criado noutro setor da habitação, podendo ter-se formalizado uma domus com dois espaços abertos aquando de sua fundação, à semelhança da domus das Carvalheiras, na primeira fase, ou da domus da Escolha Velha da Sé/rua Frei Caetano Brandão, em cujo quarteirão havia duas habitações no período alto imperial, cada um com o seu peristilo, mas que, no século $\mathrm{IV}$, foi ocupado por uma única casa e teve um dos espaços abertos transformado num oecus e numas termas (Magalhães, 2019). Por outro lado, não é possível descartar a possibilidade da reforma da casa ter sido ainda maior e que um novo peristilo tenha sido construído noutro espaço da casa, ou que a habitação tenha recorrido a outros elementos de organização e distribuição dos compartimentos fechados. 


\section{CONSIDERAÇÕES FINAIS}

Podemos atestar que os vestígios identificados no Tabuleiro A dos Terrenos da Santa Casa da Misericórdia de Braga revelam-se deveras importantes para a compreensão da sequência de ocupação do quadrante sudeste da cidade romana de Bracara Augusta. A sua análise permitiu ampliar os conhecimentos sobre a arquitetura doméstica na cidade romana, quer em período alto imperial, quer em período tetrárquico, bem como compreender a articulação desse edifício privado com o espaço urbano.

Comparativamente a outras áreas da cidade melhor estudadas, verificamos que este quadrante apresenta o mesmo tipo de construções de carácter habitacional e um crescimento urbanístico semelhante, no qual se verifica a ocupação dos quarteirões residenciais a partir da segunda metade do século I. Nos finais do século III/inícios do IV, com a elevação da cidade a capital da nova província da Gallaecia, observam-se reformas nas domus, globalmente representadas pela ampliação dos programas decorativos e pela implantação de espaços balneares.

Deste modo, apesar das limitações encontradas, uma vez que nesta área não foi possível realizar um estudo arqueológico muito aprofundado, consideramos os vestígios desta intervenção deveras importantes para o continuado estudo da cidade de Bracara $\mathrm{Au}$ gusta, pelo seu carácter mais periférico relativamente aos equipamentos públicos conhecidos que se concentram as áreas a norte e poente do forum.

\section{BIBLIOGRAFIA}

ALVES, Mafalda (2016) - Da utilização e análise de dados de Geofisica em contextos arqueológicos: o Castro de Sapelos (Boticas) e o Seminário Conciliar de São Pedro e São Paulo (Braga). Braga: Universidade do Minho (Dissertação de Mestrado).

DELGADO, Manuela; MARTINS, Manuela; LEMOS, Francisco (1989) - Salvamento de Bracara Augusta. Forum. Braga. 6 , pp. 3-40.

FERNANDES, Lara (2018) - Urbanismo e arquitetura do quadrante sudeste da cidade romana de Bracara Augusta entre a época fundacional e a Antiguidade Tardia. Braga: Universidade do Minho (Dissertação de Mestrado).

MAGALHÃES, Fernanda (2010) - Arquitectura doméstica em Bracara Augusta. Braga: Universidade do Minho (Dissertação de Mestrado).
MAGALHÃES, Fernanda (2019) - A domus Romana no Noroeste Peninsular: Construção, Arquitetura e Sociabilidades. Braga: Universidade do Minho (Tese de Doutoramento).

MARTINS, Manuela (1995) - Bracara Augusta, uma cidade na periferia do Império. In Actas do Colóquio Internacional de Arqueologia "Los finisterres atlanticos en la antiguedad" (época préromana e romana). Gijon, pp. 121-128.

MARTINS, Manuela (2004) - Urbanismo e arquitectura em Bracara Augusta. Balanço dos contributos da Arqueologia Urbana. In Simulacra Romae. Roma y las capitales provinciales del Occidente Europeo: Estúdios arqueológicos. Tarragona, pp. 149-174.

MARTINS, Manuela (2009) - Bracara Augusta. Panorama e estado da questão sobre o seu urbanismo. In DOPICO CAINZOS, María; RODRÍGUEZ ALVAREZ, Patrícia; VILLANUEVA ACUÑA, Manuel, eds. - Do Castro à Cidade. A Romanización na Gallaecia e na Hispania indoeuropeia, Actas do Curso de Actualización sobre a romanizacion de Galiza. Lugo, pp. 167-198.

MARTINS, Manuela (2014) - Projeto de Bracara Augusta. 38 anos de descoberta e estudo de uma cidade romana. Revista da faculdade de letras. Ciências e técnicas do património. Porto. Vol. XIII, pp. 165-175.

MARTINS, Manuela; DELGADO, Manuela (1989-9o)-História e arqueologia de uma cidade em devir: Bracara Augusta. Cadernos de Arqueologia. Braga. Série II. 6/7, pp. 11-39.

MARTINS, Manuela; RIBEIRO, Maria; RIBEIRO, Jorge; MAR, Ricardo (2017) - Topografia e urbanismo fundacional de Bracara Augusta. In DOPICO CAÍNZOS, María; VILLANUEVA ACUÑA, Manuel, eds. - In Roma nata, per Italiam fusa, in provincias manat. A cidade romana no noroeste: novas perspectivas. Lugo: Servizo de Publicacións da Deputación de Lugo (Philtáte. Studia et acta antiquae Callaeciae; Vol. 2), pp. 203-226. 


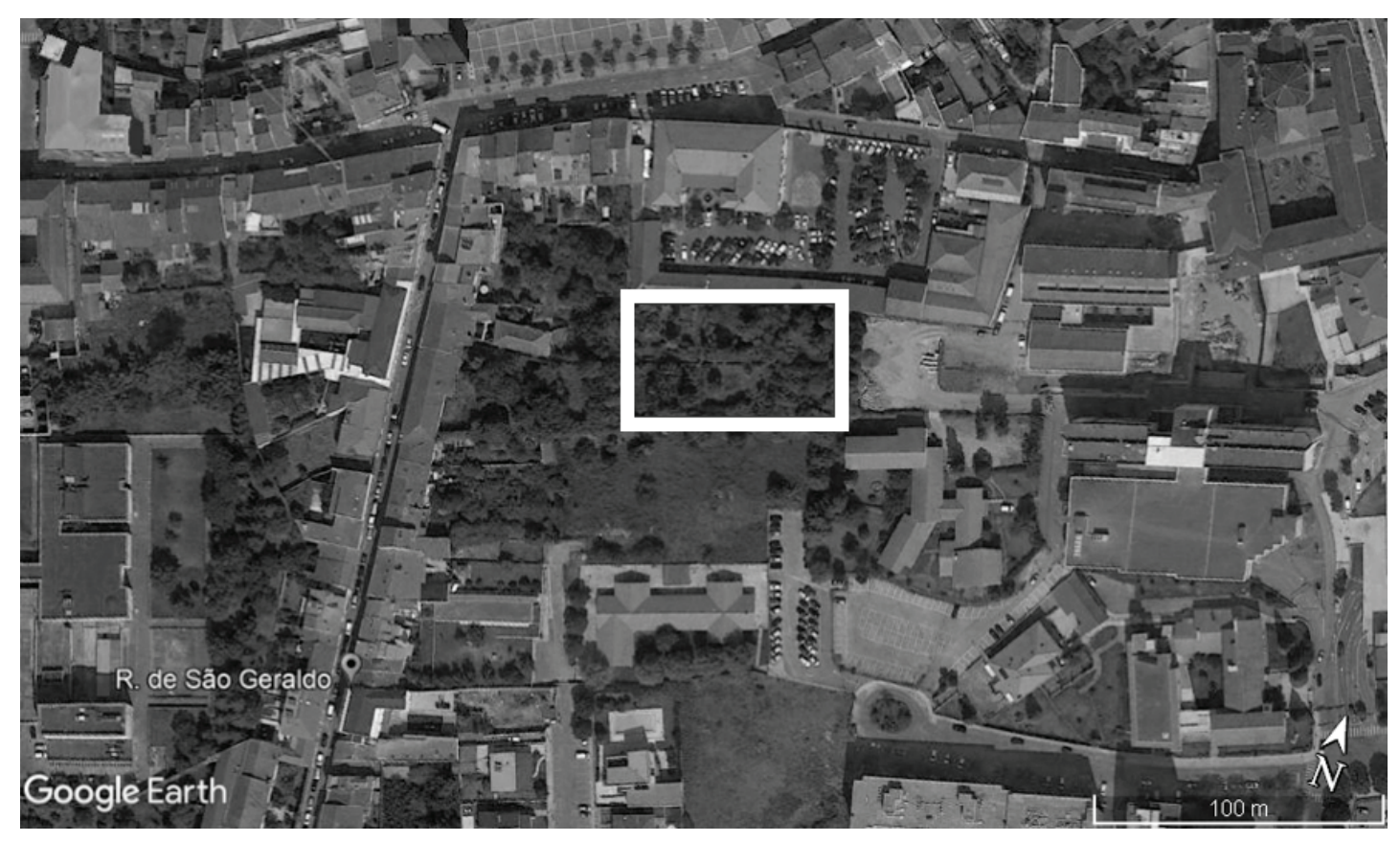

Figura 1 - Localização do Tabuleiro A dos Terrenos da Santa Casa da Misericórdia de Braga (@ Google Earth).

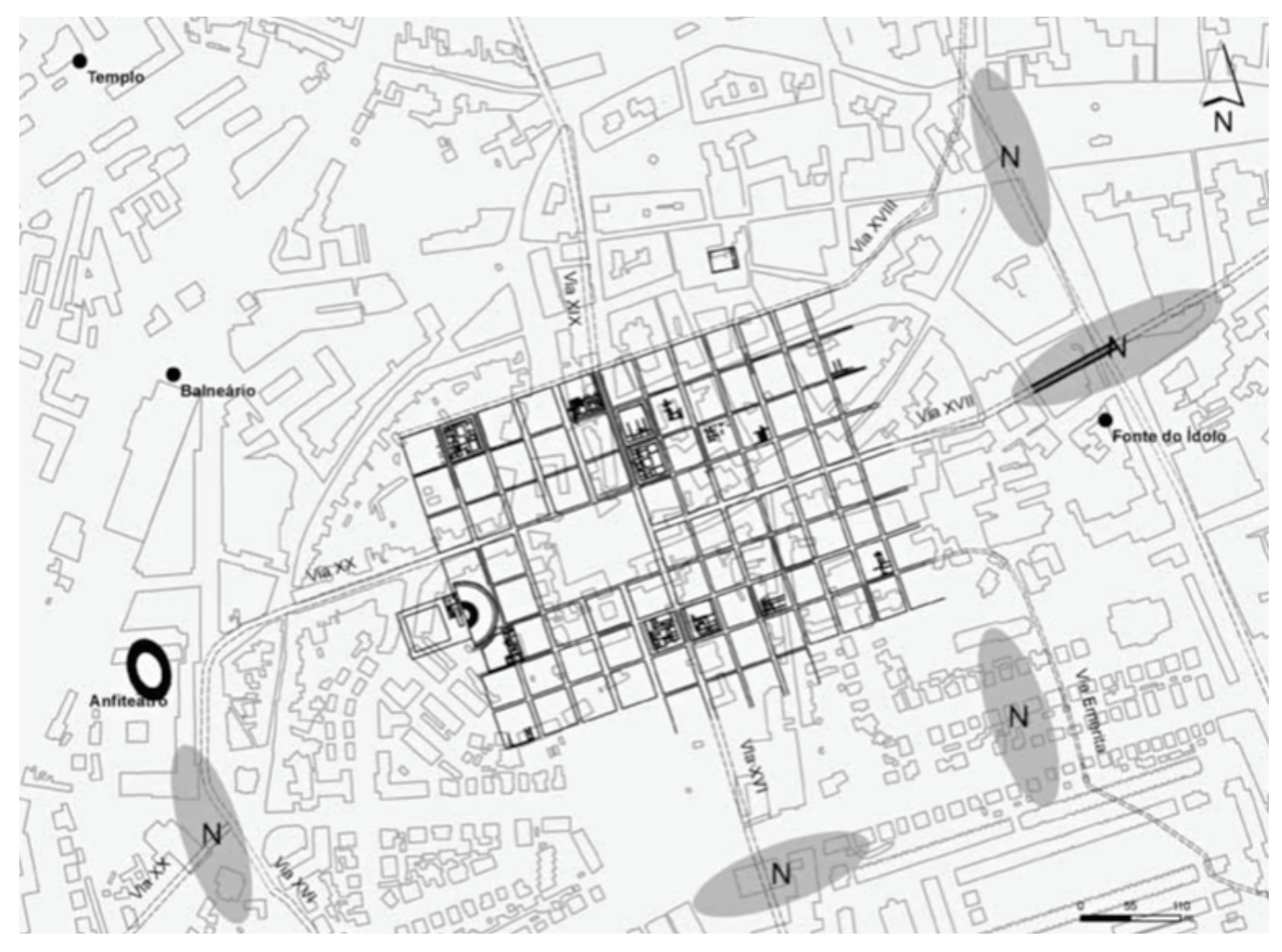

Figura 2 - Malha urbana de Bracara Augusta (Martins \& alii., 2017). 


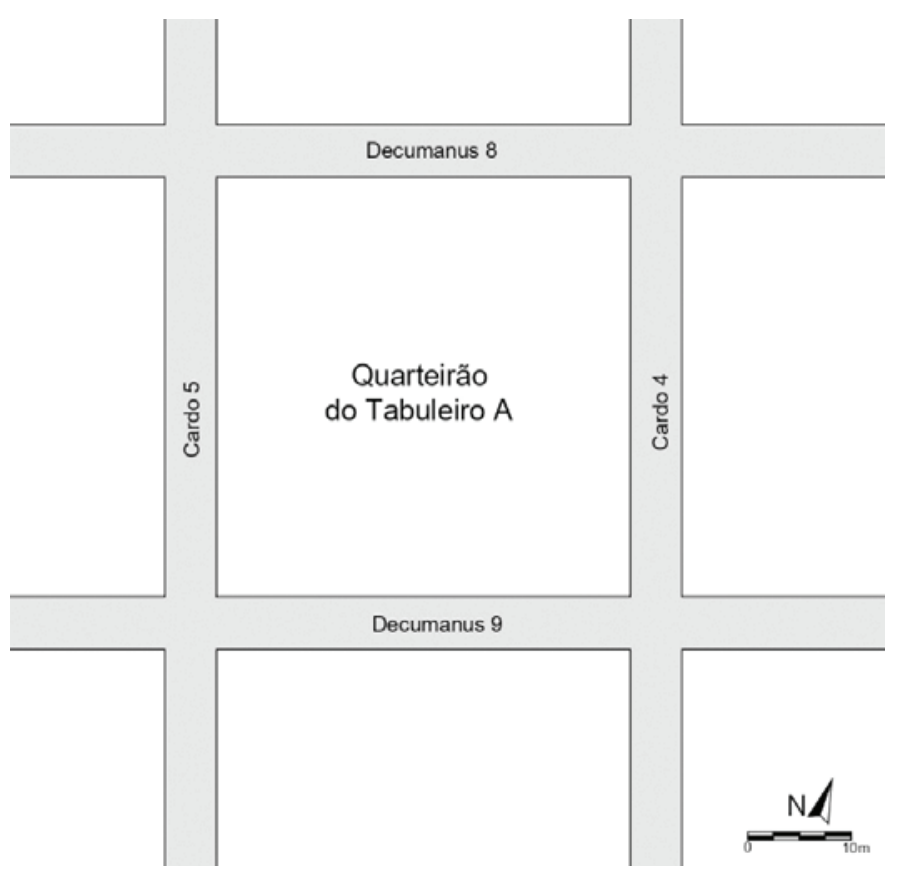

Figura 3- Quarteirão da zona arqueológica do Tabuleiro A inserido na malha urbana de Bracara Augusta (Fernandes, 2018).

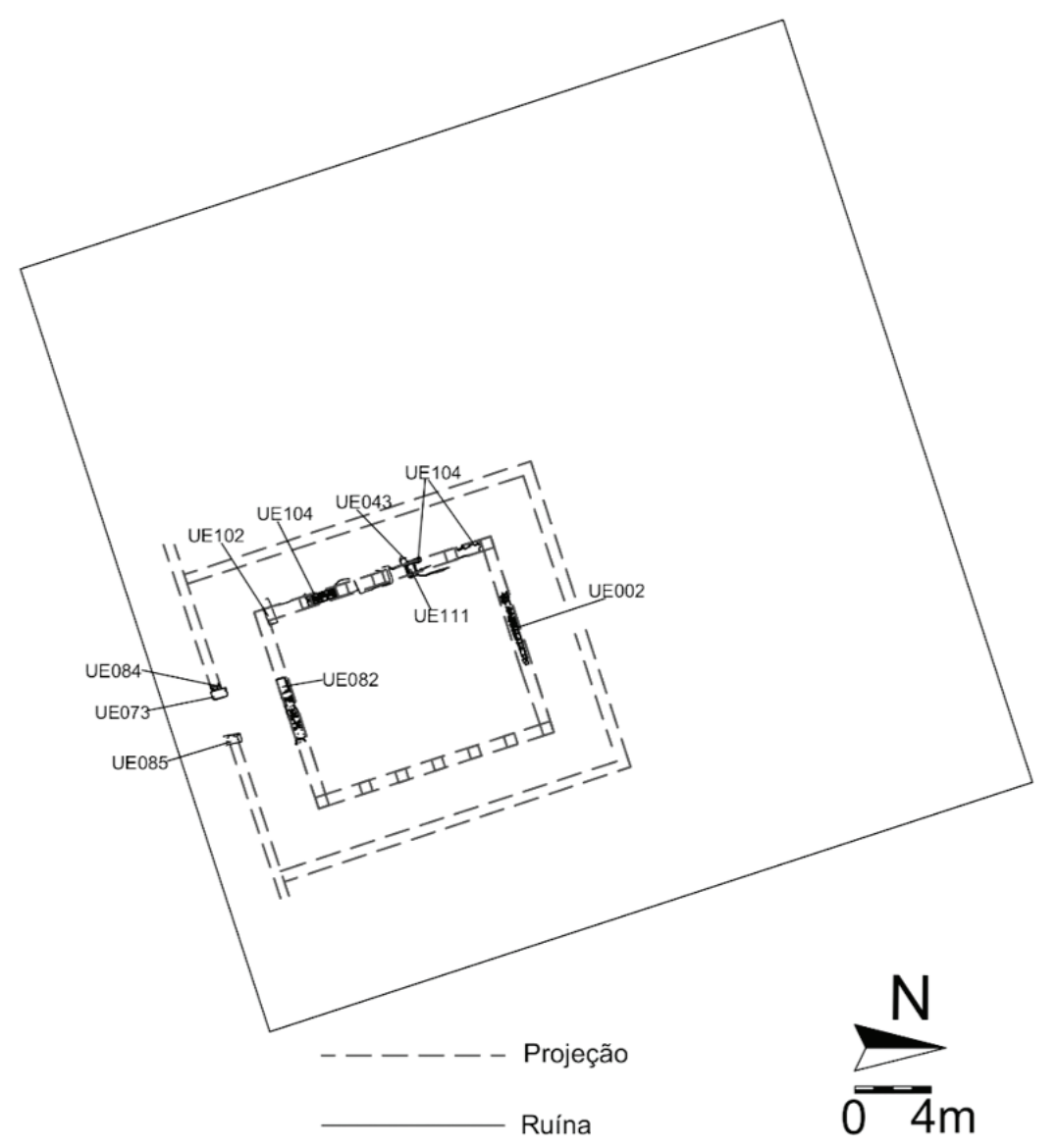

Figura 4 - Fase 1 do Tabuleiro A sobre a malha urbana (Fernandes, 2018). 


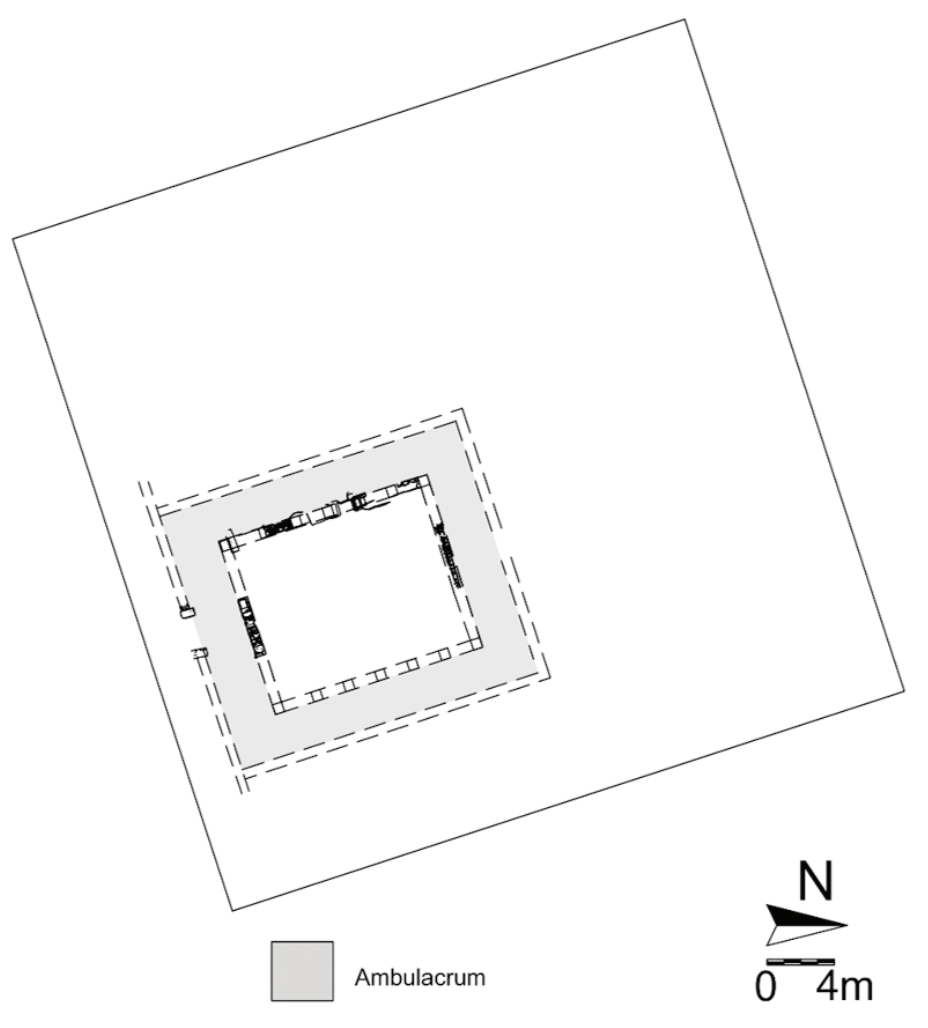

Figura 5 - Área do ambulacrum do peristilo da $1^{\underline{a}}$ fase de ocupação do Tabuleiro A (Fernandes, 2018).

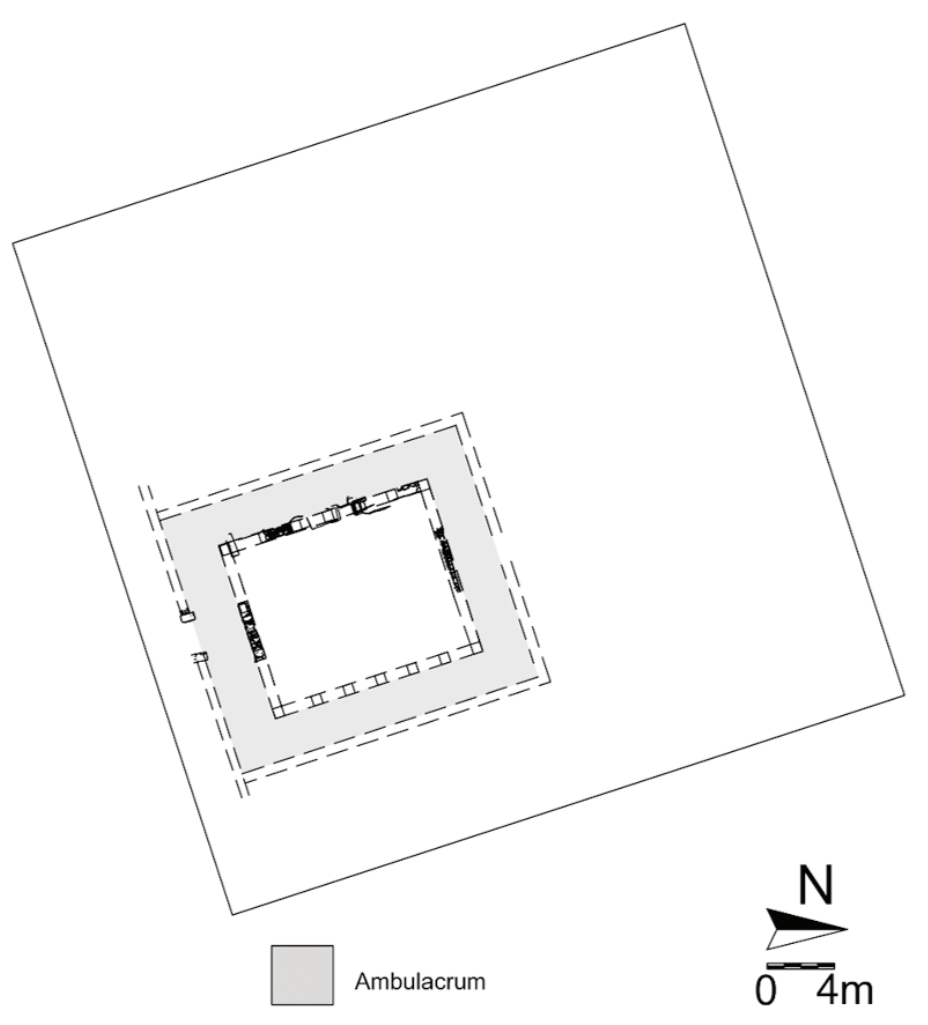

Figura 6 - Fase 2 do Tabuleiro A sobre a malha urbana (Fernandes, 2018). 



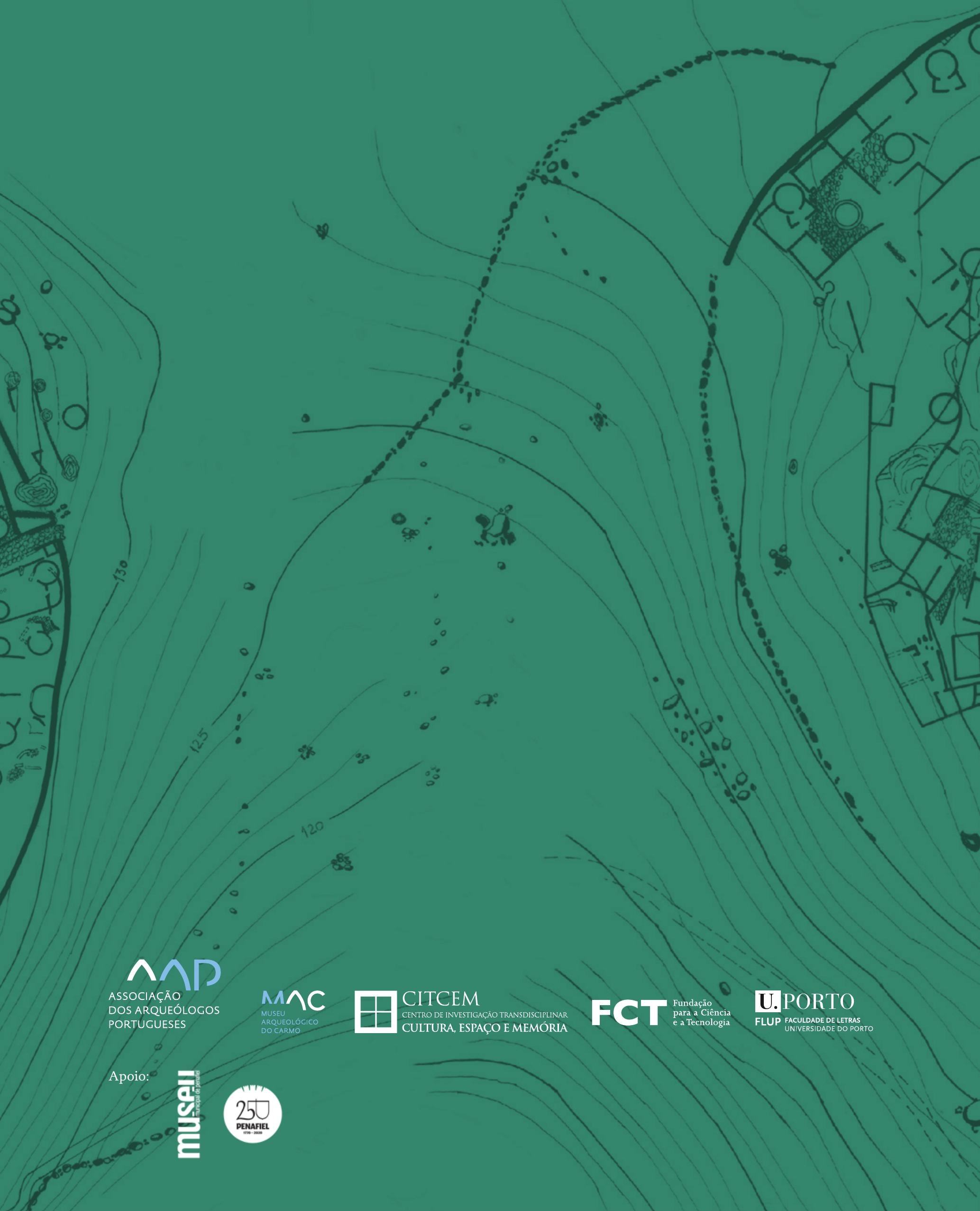

